\title{
A new species of the genus Epitettix Hancock, 1907 (Orthoptera: Tetrigidae: Cladonotinae) from Vietnam
}

\author{
Новый виА рода Epitettix Hancock, 1907 \\ (Orthoptera: Tetrigidae: Cladonotinae) из Вьетнама
}

\author{
S.Yu. Storozhenko \\ С.Ю. Стороженко
}

Institute of Biology and Soil Science, Far Eastern Branch of the Russian Academy of Sciences, Vladivostok, 690022, Russia. E-mail: storozhenko@ibss.dvo.ru

Биолого-почвенный институт ДВО РАН, Владивосток 690022, Россия.

KEY WORDS: Orthoptera, Tetrigidae, Cladonotinae, Epitettix, new species, South-East Asia.

КЛЮЧЕВЫЕ СЛОВА: Orthoptera, Tetrigidae, Cladonotinae, Epitettix, новый вид, Юго-Восточная Азия.

ABSTRACT. Epitettix striganovae sp.n. is described from Vietnam. The new species is similar to $E$. punctatus from Borneo, E. dammermanni from Java and E. tamulus from India, but clearly distinguished by the shape of pronotum and by the colour of hind tibia.

РЕЗЮМЕ. Из Вьетнама описывается Epitettix striganovae sp.n. Новый вид близок к E. punctatus c Борнео, E. dammermanni с Явы и E. tamulus из Индии, но отличается от них формой переднеспинки и окраской задних голеней.

\section{Introduction}

Up to now the genus Epitettix Hancock, 1907 includes ten species distributed in Java, Borneo, New Guinea, India and Madagascar [Eades et al., 2012]. Originally Epitettix included only the type species, $E$. punctatus Hancock, 1907 from North Borneo [Hancock, 1907]. Acridium emarginatum described from New Guinea by Haan [1843] was transferred to Epitettix by Willemse [1928]. Four species, E. fatigans Günther, 1938, E. humilicolus Günther, 1938, E. lativertex Günther, 1938 and E. tumidus Günther, 1938, was described from New Guinea [Günther, 1938]. Later the same author described additional three species, E. dammermanni Günther, 1939 from Java, E. tamilus Günther, 1939 from the Cochin located on Malabar Coast of India, and E. elytratus Günther, 1939 from the East Himalayas in India [Günther, 1939]. Latter species was redescribed and illustrated by Shishodia [1991]. Finally E. spheniscus Günther, 1974 was described from Madagascar [Günther, 1974]. Thus, representatives of the genus Epitettix never mentioned from Thailand, Vietnam and continental part of Malaysia [Blackith, 1992].

Two specimens of new Epitettix species were collected in Vietnam by D.N. Fedorenko. All specimens are dry and pinned. The description of this species is given below. The morphological terminology follows Storozhenko and Paik [2007]. Holotype and paratype of new species are deposited in the Zoological Institute of the Russian Academy of Sciences (St. Petersburg).

\section{Systematic part}

Family Tetrigidae Rambur, 1838

Subfamily Cladonotinae Bolivar, 1887

Genus Epitettix Hancock, 1907

Epitettix striganovae Storozhenko, sp.n. Figs 1-9.

TYPE MATERIAL. Holotype, female, VIETNAM: Lam Dong Province, environs of Long Lanh, Bi Doup - Nui Ba Nature Reserve, $12^{\circ} 10^{\prime} \mathrm{N}, 108^{\circ} 40^{\prime} \mathrm{E}, 1400-1900 \mathrm{~m}, 1-22 . I V .2008$, coll. D. Fedorenko. Paratype, male, same data as in holotype.

DESCRIPTION. Female (holotype). Body robust, medium sized for genus. Antennae filiform, 15-segmented; antennal bases situated on the level of lower margin of eyes. Length of antennae 1.1 times longer than length of fore femur; mid segments of antennae 3.5-4 times as long as wide. Eyes not protruding above vertex in lateral view. Fastigium of vertex granulated, slightly produced in front of eyes from dorsal aspect, 1.9 times wider than width of one eye from above; anterior margin of fastigium broadly rounded, median carina of fastigium distinct; lateral carinae elevated. Frontal ridge in lateral view almost straight, only with weak excision between eyes. Length of median carina of frontal ridge 2.6 times longer than width of 1 st antennal segment. Width of frontal ridge near base of antennae 1.8 times more than width of 1 st antennal segment. Pronotum densely granulated, not reaching apex of abdomen; anterior margin of pronotum in dorsal view slightly angularly projecting; posterior process of pronotum in dorsal view with broadly rounded 

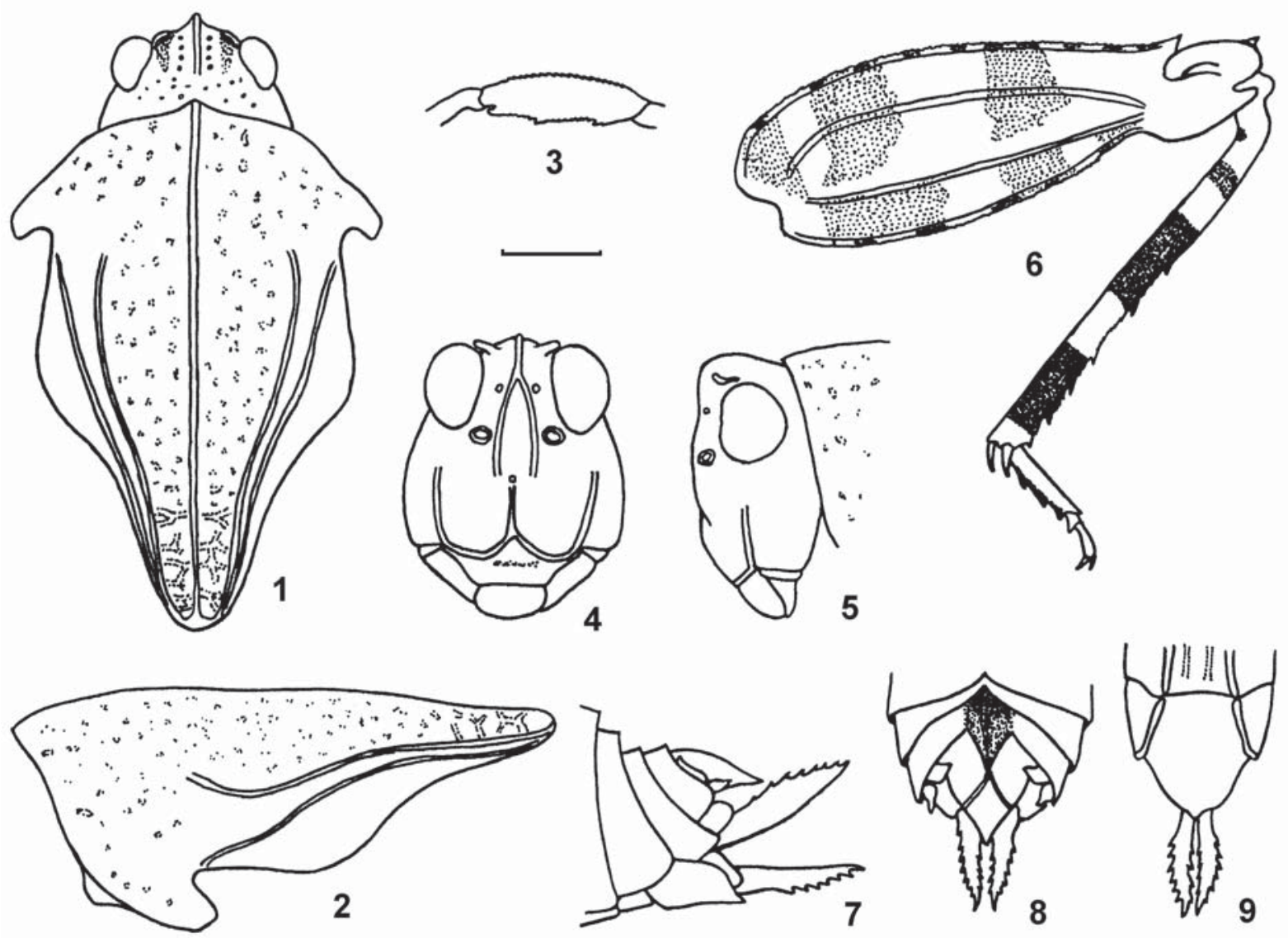

Figs. 1-9. Epitettix striganovae sp.n.: 1 - male head and pronotum, dorsal view; 2 - male pronotum, lateral view; 3 - male fore femur, lateral view; 4 - female head, frontal view; 5 - the same, lateral view; 6 - female hind leg, lateral view; 7 - female apex of abdomen, lateral view; 7 - the same, dorsal view; 7 - the same, ventral view. Scale bar: $1 \mathrm{~mm}$.

Рис. 1-9. Epitettix striganovae sp.n.: 1 - голова и переднеспинка самца сверху; 2 - переднеспинка самца сбоку; 3 - передняя голень самца сбоку; 4 - голова самки спереди; 5 - то же сбоку; 6 - задняя нога самки сбоку; 7 - вершина брюшка самки сбоку; 8 - то же сверху; 9 - то же снизу. Масштабная линейка 1 мм.

apex. Median carina of pronotum almost straight in profile; lateral carinae in prozona reduced. Hind margin of lateral lobes of pronotum with lower sinus only; posterior angles of lateral lobes in dorsal view truncated. Tegmina and hind wings absent. Fore and mid femora with sinuate and finely dentate lower carinae, upper carinae smooth. Fore femur 3.3 times, mid femur 3.6 times as long as wide. Hind femur stout, 2.4 times as long as wide; upper and lower carinae finely serrated. Upper side of hind tibia with 6 outer and 6 inner teeth and numerous denticles between them. First tarsal segment of hind legs 2.5 times longer than 3rd segment (without claws). Subgenital plate 1.3 times as long as wide, with angularly rounded posterior margin. Cerci 1.4 times as long as wide near base, with pointed apex. Valves of ovipositor narrow, dentate. Upper valve of ovipositor 4.3 times longer than its maximum width. Lower valve of ovipositor 6.3 times longer than its maximum width.

Body brown, with blackish and light brown spots on pronotum and legs. Head dark brown. Antennae light brown with blackish apex. Dorsal side of pronotun brown, lateral lobes light brown. For and mid femora light brown with indistinct blackish spots. For and mid tibiae light brown, with large black spot in apical third. Hind femora blackish brown, with three oblique light brown stripes. Hind tibiae black, with two light rings, one near the middle and another near the base of tibia. Abdomen light brown with two black longitudinal stripes on the lateral sides of tergites. Ovipositor brown.

Male (paratype). Similar to female. Antennae 16segmented; length of antennae 1.2 times longer than length of fore femur; mid segments of antennae 3.8-4 times as long as wide. Fastigium of vertex 2.2 times wider than width of one eye from above. Length of median carina of frontal ridge 2.3 times longer than width of 1 st antennal segment. Width of frontal ridge near base of antennae 1.7 times more than width of $1 \mathrm{st}$ antennal segment. Pronotum as in female, but shorter. Tegmina and hind wings absent. Fore and mid femora as in female, but lower carinae less dentate. Fore femur 
3.4 times, mid femur 3.8 times as long as wide. Hind femur 2.4 times as long as wide; upper and lower carinae almost smooth. Upper side of hind tibia with 7 outer and 7 inner teeth and numerous denticles between them. First tarsal segment of hind legs 2.4 times longer than 3rd segment (without claws). Epiproct narrow triangular, with pointed apex. Subgenital plate short, with excised apex. Cerci 1.6 times as long as wide, with pointed apex.

Body completely dark brown, except antennae, abdomen and tibiae. Antennae coloured as in female. Abdomen blackish with two light brown longitudinal stripes. For and mid femora black with 2-3 indistinct light brown rings. Hind tibiae black, with two small light rings.

MEASUREMENTS (in mm). Length of body (from frontal ridge to apex of subgenital plate) male 9.5, female 9.6; pronotum male 5.5, female 6.7 ; antenna male 2 , female 2.2 ; fore femur male 1.7 , female 2 ; mid femur male 2.3, female 2.5; hind femur male 5.1, female 5.7; ovipositor 1.5.

DISTRIBUTION. Vietnam.

DIAGNOSIS. The new species is similar to E. punctatus from Borneo and E. dammermanni from Java. It clearly distinguished from former by short pronotum and colour of hind tibia (in E. punctatus pronotum reaching the apex of abdomen and hind tibia light brown with two dark brown rings, one near the middle and another near the base of tibia), and from latter by lacking of lateral carinae in prozona, by narrow valves of ovipositor, and by colour of hind tibia (in E. dammermanni lateral carinae in prozona distinct, valves of ovipositor broad, and hind tibia coloured as in E. punctatus). The new species is most similar to E. tamulus from India, but clearly distinguished by less raised median carina of pronotum and by rounder apex of posterior process of pronotum (in E. tamulus median carina distinctly raised in anterior part of pronotum, the apex of posterior process excised, and lateral carinae in prozona distinct).

ETYMOLOGY. The new species is named in honor of the Russian entomologist Prof. Bella Rafailovna Striganova.
Acknowledgements

I am grateful to Dr. D.N. Fedorenko (Russia-Vietnam Tropical Center) for providing of the specimens of new species. The present investigation was partly supported by grants of the Russian Foundation for Basic Research \# 10-04-00682 and the Far Eastern Branch of the Russian Academy of Sciences \# 12-I-П30-03.

\section{References}

Blackith R.E. 1992. Tetrigidae (Insecta: Orthoptera) of South-East Asia: Annotated catalogue with partial translated keys and bibliography. Ireland: JAPAGA, Rockbottom, Ashford Co. 248 pp.

Eades D.C., Otte D., Cigliano M.M., Braun H. 2012. Orthoptera Species File Online. Version 2.0/4.0 // Available on: http:// Orthoptera.SpeciesFile.org. (Retrieval date: 2012/2/10).

Günther K. 1938. Acrydiinen (Orthoptera, Acrididae) von Neu Guinea, hauptsächlich aus den Ausbeuten von Professor Dr. Bürgers (Deutsche Kaiserin Augusta Fluss-Expedition 191213), Dr. E. Mayr (1928), G. Stein (1931) und Miss L. Cheesman (1933-34) // Nova Guinea, new series. Vol.2. P.1-46.

Günther K. 1939. Revision der Acrydiinae (Orthoptera), III Sectio Amorphopi (Metrodorae Bol. 1887, auct.) // Abhandlungen und Berichte aus den Staatlichen Museen für Tierkunde und Völkerkunde in Dresden. Bd.20. Reihe A: Zoologie. Neue Folge Bd.1. H.1. S.16-335.

Günther K. 1974. Beitrag zur Kenntnis der Tetrigoidea (Orthoptera, Caelifera) von Madagascar und von Mauritius // Bulletin du Musee d'Histoire Naturelle de Paris. 3e Serie. Zoologie. Vol.236. P.937-1031.

Haan W., de. 1843. Bijdragen tot de kennis der Orthoptera // Temminck (ed.). Verhandelingen over de Natuurlijke Geschiedenis der Nederlansche Overzeesche Bezittingen, de Leden der Natuurkundige Commissie in Indië en andere Schrijvers. Pts.19-20. P. 165-228.

Hancock J.L. 1907. Studies of the Tetriginae (Orthoptera) in the Oxford University Museum // Transactions of the Royal Entomological Society of London. Vol.2. P.213-244 + p1.21.

Shishodia M.S. 1991. Taxonomy and zoogeography of the Tetrigidae (Orthoptera: Tetrigoidea) of North Eastern India // Records of the Zoological Survey of India. Occasional Paper No.140. P.1204.

Storozhenko S.Yu., Paik J.-Ch. 2007. Orthoptera of Korea. Vladivostok: Dalnauka. $232 \mathrm{pp}$.

Willemse C. 1928. Révision des Acridoidea, déscrites par de Haan, avec description de nouvelles espèces // Zoologische Mededelingen. Vol.11. P.1-27. 